Meta

Journal des traducteurs

Translators' Journal

\title{
The Translation of Culture-Bound Elements into Finnish in the Post-War Period
}

\section{Irma Hagfors}

Volume 48, numéro 1-2, mai 2003

Traduction pour les enfants

Translation for children

URI : https://id.erudit.org/iderudit/006961ar

DOI : https://doi.org/10.7202/006961ar

Aller au sommaire du numéro

Éditeur(s)

Les Presses de l'Université de Montréal

ISSN

0026-0452 (imprimé)

1492-1421 (numérique)

Découvrir la revue

Citer cet article

Hagfors, I. (2003). The Translation of Culture-Bound Elements into Finnish in the Post-War Period. Meta, 48(1-2), 115-127. https://doi.org/10.7202/006961ar
Résumé de l'article

Les éléments de culture en traduction, comme les noms propres et la nourriture, fixent non seulement l'histoire d'un livre dans une culture particulière, mais impliquent aussi certaines valeurs et créent une atmosphère. Ces éléments ont aussi une influence sur la manière dont le lecteur s’identifie à l'histoire et aux personnages. Ainsi, il est fondamental de trouver la bonne stratégie de traduction. Cet article utilise la traduction finnoise (1949) de Kenneth Grahame The Wind in the Willows (1908), un livre multicouche plein d'allusions et dont l'histoire se passe en Angleterre pendant la période edwardienne. La traduction réfère à une période où la culture britannique n'était pas encore bien connue en Finlande. L'article montre que certaines incohérences d'éléments culturels dans la traduction rendent la compréhension difficile pour les lecteurs, surtout en ce qui a trait aux personnages. Des incohérences semblables se retrouvent dans d'autres traductions finnoises de livres pour enfants datant de la même période. Ces constatations peuvent s'expliquer par des connaissances limitées des cultures étrangères dans la Finlande d'après-guerre.
Ce document est protégé par la loi sur le droit d'auteur. L'utilisation des services d’Érudit (y compris la reproduction) est assujettie à sa politique d'utilisation que vous pouvez consulter en ligne.

https://apropos.erudit.org/fr/usagers/politique-dutilisation/ 


\title{
The Translation of Culture-Bound Elements into Finnish in the Post-War Period
}

\author{
I RMA HAGFORS \\ University of Helsinki, Helsinki, Finland \\ irma.hagfors@welho.com
}

\begin{abstract}
RÉSUMÉ
Les éléments de culture en traduction, comme les noms propres et la nourriture, fixent non seulement l'histoire d'un livre dans une culture particulière, mais impliquent aussi certaines valeurs et créent une atmosphère. Ces éléments ont aussi une influence sur la manière dont le lecteur s'identifie à l'histoire et aux personnages. Ainsi, il est fondamental de trouver la bonne stratégie de traduction. Cet article utilise la traduction finnoise (1949) de Kenneth Grahame The Wind in the Willows (1908), un livre multicouche plein d'allusions et dont l'histoire se passe en Angleterre pendant la période edwardienne. La traduction réfère à une période où la culture britannique n'était pas encore bien connue en Finlande. L'article montre que certaines incohérences d'éléments culturels dans la traduction rendent la compréhension difficile pour les lecteurs, surtout en ce qui a trait aux personnages. Des incohérences semblables se retrouvent dans d'autres traductions finnoises de livres pour enfants datant de la même période. Ces constatations peuvent s'expliquer par des connaissances limitées des cultures étrangères dans la Finlande d'après-guerre.
\end{abstract}

\begin{abstract}
Culture-bound elements, such as proper names and food items, not only place the story of a book in a specific culture and period of time, but also imply certain values and create an ambience. These elements also have an effect on how the reader identifies with the story and characters. Thus, it is important to find the most appropriate strategy to translate such elements. This paper considers the Finnish translation (1949) of Kenneth Grahame's The Wind in the Willows (1908), a multi-layered and allusive children's book set in Edwardian England, and some other children's tales translated into Finnish around the same era. The translation of The Wind in the Willows dates back to a period of time when British culture was not yet well known in Finland. The paper argues that certain inconsistencies in the translation of culture-bound elements in the book make it difficult for target text readers to understand its layers of meaning and to identify with the characters. Similar inconsistencies in the translation of culture-bound elements are found in other Finnish translations of children's books from the same period. The findings may be explained by a limited knowledge of foreign cultures in post-war Finland.
\end{abstract}

\section{MOTS-CLÉS/KEYWORDS}

culture-bound elements, translation norms, foreignization, domestication, children's classics

\section{Introduction}

Like Lewis Carroll's Alice's Adventures in Wonderland (1865) or A.A. Milne's Winniethe-Pooh (1926), Kenneth Grahame's The Wind in the Willows (1908) is one of the children's classics that are said to have defined the course of children's literature. 
Written during the "golden age" (ca 1862-1930) of British children's literature, this quintessentially English book is firmly set in a specific historical and social era. In this paper, my intention is to discuss what happens when such a culture-bound story is translated into another language. How do the choice of global and local translational strategies affect the story? How is a reader in a different time and culture able to identify with the story?

"All texts reflect the period of time and culture when they were written" (Oittinen 1997:13, my translation). This is what Riitta Oittinen discovered when she studied three different Finnish translations of the British children's classic Alice's Adventures in Wonderland (1865). Each of these translations was made by a different translator in a different period of time. Oittinen's aim was to examine how each period of time and the contemporaneous stage of Finnish culture had affected the translations.

This paper outlines a research project based on Oittinen's work, applying her ideas to the Finnish translation of The Wind in the Willows and of other children's books translated into Finnish around 1950. Grahame's classic was translated into Finnish by Eila Piispanen in 1949. Unlike Alice's Adventures in Wonderland, which has now reached its fourth Finnish translation, Grahame's book exists in Finnish unabridged in only this one early translation, which is still on sale today. The same applies to the other children's classics studied for this paper. In addition to The Wind in the Willows, I have looked at L.M. Montgomery's Emily of New Moon (1923-1927) and Anne of Green Gables (1908-1921) novels, as well as the Swedish author Gösta Knuttson's Pelle Svanslös (1939-1951) novels. These books have been translated into Finnish by Hilja Vesala (1920-1962), I.K.Inha (1928-1948) and Terttu Liukko (19431952) respectively and have been chosen for this paper because of the similarities they share with The Wind in the Willows. They are all very culture-bound stories set in a specific culture and time, different from that of the target text culture. Where The Wind in the Willows is a quintessentially British story, 'Canadianness' is an essential feature of the books by L.M. Montgomery. As for Knuttson's Pelle Svanslös novels, not only do they reflect their own culture and time but they also have the same type of multilayered structure seen in Grahame's book, as I will point out in a later section.

The initial focus of this project is the analysis of the translation of culturebound elements. These have been chosen as the focus of the study not only because they demonstrate the culture and period of time when the book was written, but also because they imply certain values and create a certain type of ambience to the story. As has been stated by Chesterman (1997), Toury (1995) et alia, research restricted to translations of a specified text type in a given socio-cultural context and a given language can provide useful information about translational norms. Thus ultimately the aim of this project is to infer possible translational norms prevailing in translated children's literature in Finland half a century ago.

Apart from an attempt to discover translational norms by discussing translation strategies used in children's fiction in Finland at a specific time, the study aims to discuss the function, meaning and purpose of culture-bound elements in children's literature. For the purpose of this paper, I will focus on culture-bound elements related to proper names and food items. This choice has been made because these elements are especially relevant throughout The Wind in the Willows and the other contemporary texts studied for this paper and play an important part in the dynamics of the story. 


\section{On the multilayered nature of The Wind in the Willows}

When Kenneth Grahame wrote The Wind in the Willows, his intention was to write a book that would be "clean of the clash of sex." In a famous letter to Theodore Roosevelt, he wrote that his story's "qualities, if any, are mostly negative - i.e. - no problems, no sex, no second meaning..." (Hunt 1994:76). Yet several scholars have observed this to be untrue and instead see the book as full of second meanings and social symbolism. There is clear class distinction between the different animal characters of the book. According to Carpenter (1985:163), Mole is a member of the upper middle class and Badger an English landed gentleman representing the old aristocracy, while weasels, stoats and other Wild Wooders represent the socially inferior working class. Although Toad's exact social position is never made clear, most scholars see him as a nouveau riche "whose family has bought its way into squirearchy" (Carpenter 1985:165) and whose actions bring shame to those members of the class who have inherited their position (Wullschläger 1995:168). Although the social symbolism in the story is clearly evident, Carpenter (1985:165) argues that its presence may still be accidental, "acquired because of the time in which it was written, rather than present strongly in its author's mind."

In his English Social History (1942), G.M. Trevelyan indicates that children's books that were intended to please both the adult and child reader were a characteristic invention of the Edwardian period (Wullschläger 1995:13). As Hunt has observed (1995), The Wind in the Willows is "that rare book that sits on the line between children's and adult literature." Allusive and multilayered, it is difficult to translate as one should take into account the two potential audiences. Carpenter (1985:169), for instance, has argued: "The Wind in the Willows has nothing to do with childhood or children, except that it can be enjoyed by the young, who thereby experience (though they do not rationally understand) what its author has to say, and are able to sense some of its resonances." According to Hunt (1995:114), it is the book's spare, witty, sardonic dialogue and the language, which is not generally oriented toward children, that makes it even more difficult to pinpoint its status in the literary system. $\mathrm{He}$ offers three ways of approaching the book:

[the first, that] it is two very different books, one for children and one for adults, spliced together; the second, that the book's density makes it inescapably an adult's book, while the anthropomorphism makes it seem like a children's book; the third, that it is clearly a children's book, and that any other status has been forced upon it by the colonizing impulses of symbol-hunting adults. (Hunt 1995:112; emphasis added)

This explains why it may be difficult to decide for the target culture which genre the book should belong to and hence, what translation strategies are appropriate. Oittinen (1995:10) has discussed the question of how decisive a factor genre is when the translator is choosing a translation strategy. If it is a decisive factor so that the translator will use different strategies depending on whether, for example, s/he is translating for adults or for children, what happens in the case of a book like The Wind in the Willows, which has two potential audiences? Oittinen (1995:27) gives as an example Cervantes' Don Quixote which, depending on the translator's choice of global strategy, could be translated, for instance, either as a "literary classic" or a "children's book." The same applies to the translation of The Wind in the Willows or any other multilayered book for two readerships, such as Daniel Defoe's Robinson 
Crusoe (1719) or Jonathan Swift's Gulliver's Travels (1726), for example. The translator faces a dilemma as the choice of strategy will most likely set the book's destiny in its target culture at least until the next translation (if any). To find the most appropriate strategy, first the translator has to decide what to him/her is the most essential aspect of the book that should be conveyed to the target culture readers.

As noted earlier, The Swedish author Gösta Knutsson's Pelle Svanslös tales are also multilayered. Although they have been written specifically for children, their socio-political allegorism might be difficult for them to understand. On the one hand, they are stories about the life and adventures of Pelle Svanslös (Peter No-tail, my translation), a cat without a tail. At another, Knutsson himself has agreed that they are stories about and against nazism, racism and other social evils. Pelle Svanslös och Taxen Max (1944; Peter No-tail and Davy Dachshund, my translation), for instance, the story of a dachshund who has only one ear, is an allegory about antiSemitism. Pelle Svanslös I Amerika (1941; Peter No-tail in the United States, my translation), on the other hand, is a story about racism and teaches that no matter what colour a cat's nose and paws are, every cat should be treated equally.

The Wind in the Willows, Pelle Svanslös and the books by L.M. Montgomery are all stories which reflect the social problems and situation of their own times. In such stories, the use of culture-bound elements such as proper names and food items is one way of demonstrating not only into which culture the story is set but also creating an atmosphere that reflects the values prevalent in that culture and period of time. When such a book is translated into another language, the translator and publisher have to decide whether they want to imply these same values for the target text readers, or whether they want to make adaptations to the text in order to fit it better into the target culture. The older and more foreign the source text, the more seriously the translator and publisher have to consider these questions. If the culture-bound elements in the translation of such a text are foreignized, is the reader able to really put his/her soul into it and identify with the characters? On the other hand, if the cultural references of a story set in a specific culture and time are domesticated, does the book lose a part of its charm? To study the issue further, I now turn in more detail to the Finnish translations of the books discussed above and look at how culturebound elements related to proper names and food items have been translated in them.

\section{One translation - two journeys}

If, as noted above, all texts are connected to a particular time and place, to a particular context, reflecting the period of time and culture when they were written, translation scholars need to pay attention to when and where particular translations were made. Different eras are governed by different types of translational norms and people have different expectations from translations at different times. As all translators are individuals, sometimes they decide to follow norms, at other times to deviate from them and introduce new ones. I will return to this point below when I discuss the Finnish translation of The Wind in the Willows and the other books studied for this project.

Oittinen (1997:9) has also stated: "Every book is a journey to a particular time and place." In those terms, The Wind in the Willows is a journey to Edwardian Britain. Despite the global translation strategy chosen by the translator, it would seem logical 
that the primary function of a translation would be to let the readers make the same journey and transport them to the same time and place as the original. Instead, readers of translations make two journeys. They are not only transported to the time and place of the original, but they are also taken to the time and place of the target text, that is, the period of time when the book was translated. In a past period, translational norms might have been very different from those that prevail in our modern culture and therefore affect our reading of the book. Thus, no translation can be studied without taking into account its background: when, where and by whom the translation was made.

At the end of the 1940s, when The Wind in the Willows was translated into Finnish, the function of translated children's literature was to some extent different from what it is today. While today one of its main functions is presumably to enrich our culture by letting us learn about foreign ones, after the wars it offered an escape from the materially and emotionally strained circumstances in a country recovering from the war (Heikkilä-Halttunen 2000). To help the readers identify with a story, culturebound elements such as proper names and food items were often domesticated, i.e., replaced with Finnish names to make the text sound more familiar to the reader. I will now proceed to examine how proper names and food items have been translated in the books studied for this project.

\subsection{From The Wind in the Willows to "the whistle in the reeds": the translation of names}

Let us begin by considering the titles of the books. Kenneth Grahame originally started to tell about the life and adventures of Toad, Mole, Rat and Badger in the form of bedside stories and letters to his son Alastair. When the stories were first published in the form of a book, it was difficult to think of a good title. Grahame's own suggestion, $\mathrm{Mr}$ Mole and his mates, was rejected by the publisher who settled with The Wind in the Reeds. This title too, however, had to be rejected, as it was too close to the name of a collection of poetry by W.B. Yeats (Hunt 1994:14). Even though The Wind in the Willows now seems like such an apt title for the book because it seems to portray the atmosphere of life at the River Bank so well, it was only adopted as a final resort (Wullschläger 1984:170).

The Finnish title of The Wind in the Willows was formed by the Finnish publisher, who copied the title of the Swedish translation (Det Susar I Säven) and named the book Kaislikossa suhisee (The Whistle in the Reeds, my translation). In northern Europe, reed is perhaps an element more commonly associated with rivers and animals that live by a river than the type of willow found on the British riverbanks referred to by Grahame. Thus the Finnish translation was given a title the target text readers would find more familiar and easier to identify with than the original. Interestingly, the Finnish title comes very close to the British publisher's original suggestion. As for the Finnish titles of the other books studied for this project, the titles of all the books in the three series mentioned above are also domesticated. Anne of Green Gables, for example, is published in Finnish as Annan nuoruusvuodet (Anna's Early Years, my translation), Emily Climbs is called Runotyttö maineen polulla (Poetry Girl on her Path to Success, my translation) and Pelle Svanslös och Taxen Max (Pelle No-tail and the dachshund Max, my translation) is named Pekka Töpöhäntä ja Mauri 
Mäyräkoira (Pekka No-tail and the dachshund Mauri, my translation).The analysis of the Finnish titles leads to a further question. How are the proper names of the characters translated in the books discussed above?

As noted earlier, the protagonists of The Wind in the Willows are animal characters called Mole, Toad, Rat and Badger. The protagonists are all male and in the narrative their names are sometimes preceeded by $\mathrm{Mr}$ (i.e. $\mathrm{Mr}$ Mole), other times with a definite article (i.e., the Mole). In a dialogue the protagonists occasionally refer to each other with terms of endearment, such as Moly and Ratty. The protagonists' enemy, the weasels and the stoats, on the other hand, are never referred to individually or by name. Instead, they are treated as a mass and only spoken of using the plural form of the name of the animal species they represent. As indicated by Hunt (1994), Carpenter (1985) and Wullschläger (1984), this technique is used to emphasise the class distinction between the different animal characters, suggesting that the protagonists represent the upper and upper middle classes and the enemy the working class. Thus the book can be read as a social drama or a social-political allegory (Carpenter 1985:165).

Let us look now at the Finnish translation. The names of the characters have been translated directly into Finnish but a different strategy has been used in the translation of the terms of endearment. Instead of thinking of specific nicknames for the protagonists or adding suffixes to the names, the translator has added affixes such as Rotta-kulta (Rat dear, my translation) and Rotta ystäväiseni (Rat my friend, my translation), a common way in Finland to illustrate a warm relationship people have when addressing each other in a dialogue. As in the source text, stoats and weasels are referred to only in plural form.

At this point I digress slightly, and briefly discuss the gender of the protagonists. In the original English version the fact that the characters are male is evident from the first page onwards, not only because at times their names are preceded by $M r$., but because they are always referred to with the pronoun he. In the Finnish language there is only one personal pronoun - hän - for both genders. Consequently, to an English reader it is evident from the very beginning that Mole, for instance, is male, the reader of the Finnish translation knows this for a fact only when Mole is introduced as Mr. Mole in the middle of the first chapter. As the first Finnish edition was unillustrated, a contemporary reader could not even rely on illustrations for clarification. Thus the fact that The Wind in the Willows is a story of four bachelors is far less evident in the Finnish translation than in the English original.

In the translation of the books by L.M. Montgomery, the protagonist's first name is always replaced with a Finnish one. Interestingly, this shift only occurs with the name of the protagonist. The names of the other characters are transferred into the translation in their foreign forms. Thus for instance in both Anne of Green Gables and Emily Climbs, the protagonists' first names are changed into the more Finnishsounding Anna and Emilia respectively. Consider the following passages. In the first example, Anne Shirley introduces herself to her adoptive parent Marilla Cuthbert.

\section{Example 1}

- Anne Shirley, reluctantly faltered forth the owner of that name, 'but oh, please do call me Cordelia. It can't matter much to you what you call me if I'm only going to be here a little while, can it? And Anne is such an unromantic name.' (Montgomery, 1997:27) 
Marilla, on the other hand, thinks that Anne is a good and sensible name. In the second example, Anne tries to reason with Marilla why her first name should at least be spelled with an e.

Example 2

- [B] ut if you call me Anne, please call me Anne spelled with an $e$.'

- 'What difference does it make how it's spelled?' asked Marilla [...]

- Oh, it makes such a difference. It looks so much nicer. When you hear a name pronounced can't you always see it in your mind, just as if it was printed out? I can; and A-N-N looks dreadful, but A-N-N-E looks so much more distinguished. If you'll only call me Anne spelled with an e I shall try to reconcile myself to not being called Cordelia.' (Montgomery 1977:27; bold emphasis added)

For Anne, the spelling of her name is an essential question of personal identity. As Davey points out, the reader never actually learns whether the protagonist's real birth name is Ann or Anne (Gammel 1999:175). In the Finnish translation, however, there is no indistinction about Anne's birth name. When she first meets Marilla, she introduces herself as Anni Shirley (Vesala 2000:28), Anni being a common, sensible first name in Finland in the 1950s. She would then like Marilla to call her Anna with an $a$ instead. Two points need to be made here. Firstly, in the Finnish translation Ann and Anne are replaced with the more Finnish-sounding Anni and Anna. Although such a decision has been made presumably to help the target text reader identify with the character, the hybrid Anni Shirley which is a combination of a Finnish first name and an English last name sounds very odd and unnatural.

Second, the original function of this passage has changed. For the reader of the source text the real birth name of the protagonist remains an unsolved mystery throughout the book, whereas in the Finnish translation it is clear from the beginning that her real name is Anni but she would prefer to be called Anna instead. As noted above, the same strategy is used in the translation of names in the Emily novels, in which Emily is replaced with the more Finnish-sounding Emilia. Curiously, the protagonist's cat Pandora's name is also switched into Tuhma-Töpö (Naughty No-tail, my translation), while the names of her parents, friends and relatives remain unaltered (e.g., Douglas Starr, Ilse, Teddy).

As for place names, the translator of Emily novels sometimes translates the names into Finnish and at other times keeps the English names. Thus Prince Edward Island and New Moon are translated into Finnish as Prinssi Edvardin saari and Uusi Kuu, while place names such as Stovepipe Town or Shrewsbury are retained in their English forms. In the same book, New Brunswick is sometimes retained in its original English form, while at other times it is translated as Uusi Brunswick. Again, the translator of the Anne of Green Gables novels has applied the same strategy and translated some of the place names such as Green Gables into Finnish (Vihervaara) but kept others in their original forms (Summerside).

In the case of The Wind in the Willows, then, most culture-bound elements related to proper names are domesticated but similarly to Anne and Emily, there is inconsistency in the translation. Most proper names are replaced with a Finnish equivalent (Bill - Ville, Tom - Tommi) or with more general terms to make them fit the Finnish target culture. All cultural references that would indicate that the story is set in Britain are deliberately omitted. Merry England is replaced with valtakunta 
(state, my translation), English stream with kotimaan joet (streams of the homeland, my translation). The type of culture-bound elements that do not automatically tie the story to England (by giving an English place name or the name of the country), on the other hand, are transferred to the Finnish target text unchanged, no matter how exotic to a Finnish contemporary reader. In a passage where Grahame describes Mole's underground house and explains that there were brackets carrying plaster statuary - Garibaldi, and the infant Samuel and Queen Victoria, and other heroes of modern Italy (Grahame 1992:106), the author is making fun of Mole's attempts to imitate an upper-middle class lifestyle. In the Finnish translation, all these names are transferred into the text directly, although the reader (child or adult) in post-war Finland, with very limited knowledge on the various implications of the British culture, can hardly have understood the meaning of the passage.

In the case of The Wind in the Willows, the inconsistency in the translator's choice of a global strategy is explained on the one hand by the translational norm, which favoured domestication. As for the inconsistency in the choice of local strategy, the translator has admitted that it can be explained by her rather limited knowledge of British culture and language (Lampio 1999). When she did not know the meaning or function of the culture-bound element in the original text, she either translated it word for word, transferred it directly to the target text, or omitted it from the translation altogether. I return to this point below when I discuss the translation of food items.

The most extreme examples of domesticating proper names in the books studied for this project are the Finnish translations of the Swedish author Gösta Knutsson's Pelle Svanslös novels. In them, the whole story is transferred from Sweden into a Finnish setting. In other words, every place name is replaced with the name of an existing Finnish street and town and every character is given a Finnish name. This strategy is also applied to the translation of food items, which I will discuss in the section below.

\subsection{From peppermint candy to fish pastry: the translation of food items}

Food often plays an important role in children's books. As Carpenter (1985:163) indicates, food and kitchen are often used as symbols of security in children' literature. In The Wind in the Willows too, food plays an important role. Delicious meals are often served after an adventure and mark a resolution. These meals are described with vivid detail and their purpose is to comfort the readers and bring them a sense of security. Often the meals consist of the finest delicacies of the Edwardian period, i.e., food items that a contemporary middle-class English reader could identify with and rejoice. However, in Finland in the 1950s, in a poor country recovering from the war, many of these elements were totally unheard of, thus complicating the translation process. As a result, there are passages in the Finnish translation, which did not easily open up to a target text reader. For a large part, most food items have been domesticated by replacing them with Finnish equivalents or less specific terms.

Thus Buggins's product (1992:114) is replaced with Niemisen valmiste (Nieminen's product, my translation), the beer label Old Burton (1992:115) with the generalisation 
vanhaa hyvää laatua (good old quality, my translation) and guava jelly (1992:286), a foreign product in post-war Finland, with the more familiar, but still extravagant ananashyytelö (pineapple jelly, my translation). Some items, although foreign in Finland at the time, such as ginger beer, are translated directly (inkivääriolut), while other items such as potted meat are omitted from the translation altogether, presumably because it was an unknown concept for the translator.

As noted above, all cultural references in the Pelle Svanslös books are replaced with Finnish ones. Knutsson often plays with words and culture-bound elements to create a humorous effect, which makes his books difficult to translate. In Trillingarna Svanslös, Pelle travels with his daughter Maj to a Swedish town called Gränne, where a traditional Swedish candy called polka gris, a red and white peppermint candy stick, is made. In Swedish the word gris means a pork and Little Maj, who has never heard of such a candy before, is scared because she is afraid that there will be a pork inside the candy. In Finnish, the name of the candy is replaced with kalakukko (fish pasty) a traditional Finnish dish from the town of Kuopio. The literal meaning of the Finnish word is fishrooster, so in the Finnish translation Pelle's daughter is afraid of encountering a strange combination of a fish and a rooster.

These translated texts support Oittinen's (1995:22) suggestion that source texts start to live a new life when they are transferred to a target culture and language, where they may be understood differently and approached from a totally different viewpoint than before. As discussed earlier, this happens with the Finnish translation of The Wind in the Willows as well. Grahame's story is full of cultural references, some of which only make sense in their British/Edwardian context. According to Carpenter (1985: 103), humour, satire and implied irony, for example, were essential ingredients of the Edwardian children's literature in England. As an example, Wullschläger cites the opening of Beatrix Potter's The Tale of the Peter Rabbitt (1902):

...don't go into McGregor's garden; your Father had an accident there; he was put in a pie by Mrs McGregor (Wullschläger, 1995:103; emphasis added).

In the first chapter of The Wind in the Willows, there is a passage with a very similar type of implied irony. In the example below, Mole has scrabbled up to the surface from his underground home and in his delight of being in the open air and running in the warm grass of a meadow, he encounters a tollgate-keeping rabbit.

'Hold up!' said an elderly rabbit at the gap. 'Sixpence for the privilege of passing by the private road!' He was bowled over in an instant by the impatient and contemptuous Mole, who trotted along the side of the hedge chaffing the other rabbits as they peeped hurriedly from their holes to see what the row was about. 'Onion sauce! Onion sauce!' he remarked jeeringly, and was gone before they could think of a thoroughly satisfactory reply. (Grahame 1992:3; emphasis added)

Compare the Finnish translation of the same passage:

'Seis!' sanoi kulkuautolla seisova iäkäs kaniini. 'Yksityistien käytöstä veloitetaan viisi markkaa!'Kärsimätön ja ylenkatseellinen Myyrä tuuppasi hänet arvelematta kumoon ja vaelsi aidanviertä kiusoitellen muita kaniineja, jotka tirkistelivät koloistaan, mikä hätänä. 'Sipulikastiketta, sipulikastiketta!' Myyrä huuteli pilkallisesti ja oli tiessään ennen kuin kaniinit ehtivät keksiä tarpeeksi nasevaa vastausta. (Piispanen 1949:6; emphasis added) 
To an English reader, it is clear what Mole's comment in the original implies. In the Finnish translation, onion-sauce is translated word for word but the implication of the passage does not easily open up to a target text reader. According to anecdotal evidence, young Finnish readers in the 1950s were utterly unable to see the point of Mole's remark, for the simple reason that rabbit was not a typical dish in post-war Finland. If it was ever served, it was never served with onion sauce.

One of the reasons why the translator may not have felt completely at ease with such ironical asides addressed mainly to adult readers might have been that in her period, such elements were rare in Finnish children's literature, which was characterized by more serious themes. In the immediate post-war years, the threat of war and the gloom of depression were common themes in Finnish children's literature (Heikkilä-Halttunen 2000). In Tove Jansson's Moomin books (1945-), for example, the Moomin Valley always represents a haven where one can escape to from the threats of destruction.

According to Heikkilä-Halttunen (2000), British fantasy literature had not been very well known in Finland before the second world war, but this began to change in the late 1940s with a change in the intellectual climate, which inspired writers and publishers to experiment with new trends such as nonsense and fantasy. This may explain why The Wind in the Willows came to be translated at this particular time.

As has been pointed out, the arguments on this paper are based on two assumptions: the children's classics discussed have been translated into Finnish only once and these translations have been made in the 1940s. These facts explain why the global and local strategies used by the translators may seem odd from a modern point of view. This leads to a further issue. As is evident from the translations analyzed in this project, target texts are always influenced and affected by changes in society, culture and language. Should not classics then be re-translated (or at least reviewed) from time to time, as already existing ones may start to feel "out-dated"? A translation is always a product of its own period of time and culture, which is why Steiner (1976:29-30) argues that classics have to be re-translated: times change and thus retranslating is the only way of keeping the texts alive. By interpreting classics from the perspective of our own time, we help to keep them as a part of our own history. This, in my opinion, is especially evident in the case of the translation of cultural references. First of all, prevailing translational norms vary greatly from one period to another. Secondly, our knowledge of other cultures changes (expands or contracts) as time goes by.

The 'Britishness' of The Wind in the Willows, The 'Canadianness' of L. M. Montgomery's books for the young girls and the 'Swedishness' of Gösta Knuttson's books about Pelle Svanslös are all essential features of the original source texts. They are the 'meat' that the stories have been written around. If they form the core of the source text, why should the target text readers not be allowed to enjoy them as well? Although identification is one of the essential functions of children's literature, it is by no means its only function. Literature can also serve as a bridge between cultures and let readers learn about the customs, values and beliefs prevalent in other cultures and periods of time. 


\section{Translation strategies as a means of bridging or obscuring cultural differences}

Depending on the choice of global and local translation strategies, translated children's literature can be either a means of bridging cultural differences or of obscuring them. If culture-bound elements are foreignized the story can serve as a tool for learning about foreign cultures, times and customs and intrigue readers to find out more about them. In other words, foreignized children's stories are a way of drawing attention to cultural matters: to learn what is different and what is shared between the reader's culture and that in which the story is set.

Based on the translations studied for this project, it seems that in the 1940s and 1950s the translational norm in Finnish children's literature was to domesticate cultural references as much as possible to help the children identify with the characters and understand the stories better. In a country recovering from war, where foreign cultures were not yet very well known, such a norm is reasonable. But 50 years later, Finland is a very different place. People know more about other cultures and are eager to learn more all the time. Thus, there is no reason why children's books should be domesticated anymore.

One of the greatest aspects of literature is that it not only entertains us, but also broadens our mind and our view of the world by providing us information about other cultures and times, other types of ideas and values than those that prevail in our own society. This applies to both literature for adults and children which is why children too should have the right to enjoy stories where cultural references are translated in a logical, consistent way.

As noted above, retranslation is a way of keeping texts alive. If publishers are not interested in retranslation, they could at least revise some of the old translations. Some of the greatest inconsistencies could be explained in footnotes or forewords. By explaining foreign elements or phemonena in this way, the reader would learn a great deal about other times and cultures. Although there are children who probably could not care less, for instance, whether Prince Edward Island where the Anna and Emily novels are set is in Canada or Timbuktu, there is surely a countless number of children who do care. With the help of an interesting story and characters they can identify with, they are intrigued to learn more about the culture where the stories have been set. Thus children's literature cannot be thought of as fiction where it does not make any difference whether the story is set in England or Never-Never land. If the author has intentionally set the story in a specific culture and context, this usually has an importance for the story, at least by putting it in a frame. The more these frames are changed in a translation, the more obscure the result may be and thus prevent the reader's capability to identify with it.

\section{Why retranslation is necessary from time to time}

As we have seen, many books that have come to be known as children's fiction are in fact multilayered stories originally written with two potential audiences in mind. In this project I have discussed The Wind in the Willows, but there are many other famous examples, such as Saint-Exupéry's Le Petit Prince (The Little Prince), to name but a few. The possibility of two audiences is something that translators and publishers 
should keep in mind when choosing the appropriate translation strategy. If children's books are domesticated without further consideration, the result may be somewhat peculiar. In Knutsson's Heja Pelle Svanlös (1946), a French girl cat escapes from the misery of post-war France to Sweden, which was a welfare state. As I have discussed earlier, in the Finnish translations, Knutsson's stories have been transferred into a Finnish setting. Thus, in the Finnish translation, the French girl cat escapes from the miseries of war to Finland, a country which had suffered from the war at least as much as France. Although a child reader may not pay attention to such an illogicality, for an adult reader it makes rather strange reading.

In addition to illogicalities, retranslating or at least revising old translations should also be considered because they may contain passages which, although acceptable 50 years ago, are politically incorrect in modern society. In The Wind in the Willows there are several passages where the protagonists smoke cigarettes and load guns and yet the Finnish translation is today presented as a book for very young children. In Pelle Svanslös och Taxen Max (Peter No-tail and Davy Dachshund, my translation), which as stated earlier is an allegory of anti-Semitism, there is a passage which has been censored from the Swedish edition from the 1970s onwards. In that passage, the evil and cruel stray cat Måns explains that animals who have any kind of defect (such as only one ear or no tail) and who are not members of the "correct" race are to be treated as slaves. In the Finnish unabridged translation on sale today, this passage (which makes ghastly reading for a child and adult alike) still remains. The translation dates from 1945.

As has been pointed out, even though the global strategy in the books studied for this paper has been more or less to domesticate the stories, translators have been inconsistent in their use of local strategies on the translation of culture-bound elements. Although domestication was a reasonable translation strategy in Finland in the 1940s, times change, societies change and our knowledge of the rest of the world changes. In short, children's books should be retranslated or at least revised every once in a while to keep them alive.

\section{Conclusion}

The future project outlined in this paper will take this discussion further. It will be complemented by an analysis of several other children's books translated into Finnish in the 1940s and 1950s. The aim is to give an account of the translation strategies used to translate culture-bound elements in children's fiction translated into Finnish in the post-war years while attempting to find explanations for these choices and see whether a translational norm could truly be reconstructed.

\section{REFERENCES}

\section{Children's literature}

Grahame, K. (1908/1992): The Wind in the Willows. Ware: Wordsworth.

Grahame, K. (1949/1966): Kaislikossa suhisee.Transl. Eila Piispanen, Porvoo: WSOY.

Knutsson, G. (1941): Pelle Svanslös i Amerika. Stockholm: Bonniers.

Knutsson, G. (1944): Pekka Töpöhäntä Amerikassa. Transl. Terttu Liukko. Helsinki: Gummerus. Knutsson, G. (1944): Pelle Svanslös och Taxen Max. Stockholm: Bonniers. 
Knutsson, G. (1945/2000): Pekka Töpöhäntä ja Mauri Mäyräkoira. Transl. Terttu Liukko. Helsinki: Gummerus.

Knutsson, G. (1946): Heja, Pelle Svanslös.Stockholm: Bonniers.

Knutsson, G. (1947): Kiri, kiri, Pekka Töpöhäntä. Transl. Terttu Liukko. Helsinki: Gummerus.

Knutsson, G. (1949): Trillingarna Svanslös. Stockholm: Bonniers.

Knutsson, G. (1949): Pekka Töpöhännän kolmoset. Transl. Terttu Liukko. Helsinki: Gummerus.

Montgomeri, L.M (1908/1964): Anne of Green Gables. London: Puffin books.

Montgomery, L.M (1920): Annan nuoruusvuodet. Transl. Hilja Vesala. Porvoo: WSOY.

Montgomery, L.M. (1923/1983): Emily of New Moon. New York: Bantam Books.

Montgomery, L.M (1926/1983): Emily Climbs. New York: Bantam Books.

Montgomery, L.M (1928): Pieni Runotyttö. Transl. I.K.Inha. Porvoo: WSOY.

Montgomery, L.M (1948/1992): Runotyttö maineen polulla.Transl. I.K. Inha, Porvoo: WSOY.

\section{Research literature}

Carpenter, H. (1985): Secret Gardens. The Golden Age of Children's Literature, Boston: George Allen \& Unwin.

Carroll, L. (1865/1992): Alice in Wonderland. Ware: Wordsworth Classics.

Chesterman, A. (1997): Memes of Translation, Amsterdam and Philadelphia, PA: John Benjamins.

Defoe, D. (1719/1998): Robinson Crusoe. Oxford: Oxford Paperbacks.

Gammel, I. (1999): L.M. Montgomery and Canadian Culture. Toronto: University of Toronto Press.

Heikkilä-Halttunen (2000): Kuokkavieraasta oman talon haltijaksi. Suomalaisen lasten-ja nuortenkirjallisuuden institutionalisoituminen ja kanonisoituminen 1940-1950-luvuilla. Helsinki: SKS.

Hunt, P. (1994): The Wind in the Willows. A Fragmented Arcadia, New York: Twayne Publishers. Hunt, P. (1991): Criticism, Theory \& Children's Literature, Oxford: Blackwell.

LAmpio (née Piispanen), Eila. Personal interview with the author. 27 October 1999.

Milne, A.A. (1934/2000): Nalle Puh. Transl. Anna Talaskivi, Porvoo: WSOY.

Oittinen, R. (1995): Kääntäjän karnevaali, Tampere: Tampere University Press.

SAINT-Exupéry, A. de (1946/1992): Le Petit Prince. Paris: Gallimard.

Swift, J. (1726/1998): Gulliver's Travels. Oxford: Oxford Paperbacks.

Toury, G. (1995): Descriptive Translation Studies and Beyond, Amsterdam and Philadelphia: John Benjamins.

WullsChläGER, J. (1995): Inventing Wonderland. The Lives and Fantasies of Lewis Carroll, Edward Lear, J.M. Barrie, Kenneth Grahame and A.A. Milne, London: Methuen. 